\title{
Restructuring Infrastructure at a Historically Disadvantaged University to Accommodate the Needs of the Visually Impaired Students
}

\author{
Ntungufhadzeni P. Mutele
}

Disabled Students Unit (DSU), University of Limpopo, South Africa

Kola O. Odeku

Faculty of Management and Law, School of Law, University of Limpopo, South Africa

Doi:10.5901/mjss.2014.v5n20p3091

\section{Abstract}

Disability affects people in many different ways such as physical, sensory, cognitive and many more. The different perception of disability impact and influence the way it should be addressed, particularly with regard to what they do need and what they do not need in order for them to function to their fullest level in any endeavour. Visually impaired people are usually perceived as vulnerable people who are permanently dependant on others, and are unable to make appropriate choices. Hence they are seen as unable to participate as worthy citizen in the scheme of things in the society at large. This group of disabled people often suffer from prejudice, social isolation and discrimination. Against this backdrop, this paper accentuates that being visually impaired does not mean that the person is disabled to the point of not being able to care and fend for self. Towards this end, the paper vehemently argues that the environment and the infrastructure where they live and function just need to be structured to become user friendly in order to accommodate them. With the necessary infrastructure and conducive environment in place, the visually impaired would also function perfectly like their able counterparts whether at home, work and more importantly at schools including tertiary institutions. Pursuant to this, restructuring becomes important to accommodate and serve visually impaired students at historically black University where, by virtue of history, they have been denied, deprived and disadvantaged in all aspects of post-secondary school education in South Africa.

Keywords: Perception, Structure, Environment, Visual impairments, University

\section{Introduction}

In South Africa, education is regarded as human right, therefore students with visually impairment should exercise this right without any discrimination (Rieser, 2012). Government together with higher learning institutions (universities) should see to it that learning conditions are improved to get rid of all barriers to the disabled. Various barriers that might be encountered by students with visual impairment may hinder their full effective participation in learning and teaching and in the society on equal basis with other students. It is important to create an accessible and inclusive environment, programmes, communication and all other services in accordance with the capabilities of all students. This calls for inclusive education (Naicker, 2005).

Inclusive education connotes that all learners have to be catered for based on their needs. Recognising the importance of this, in 2001, the Department of Works in South Africa published a Guideline on Standard Electrical, Mechanical and Architectural Guideline for the Design of Accessible Buildings (facilities for disabled persons) (DPWSG, 2001). This guideline prescribed succinctly the design and standard expected in all buildings to take care of disabled persons. As part of the rights of disabled people, these standards are expected to be provided and met as part of an inclusive education, where the structure and architectural designs of the university environment will make this realisable. However, this can only be achieved if the people who are at the helm of the management affairs implement the guidelines.

Students with visual impairments remain one of the main groups being widely excluded and recognised as one of the least visible and most potent factors in educational marginalisation. In order for the needs of visual impaired students to be realised, universities need to provide support services. For example disability unit and employed professional staff who have knowledge of appropriate and alternative approaches, means and formats of communication, educational procedures and materials to support students with visual impairments.

These days, the issues of concern and how to make life more comfortable for visually impaired people are being 
discussed in national and international forum. One of the key issues is how to ensure that they are able to navigate spaces like their able counterpart with little or no barriers. Against this backdrop, making infrastructural amenities more accessible and user friendly to meet the standard of the visually impaired people in the society and wherever they might be become very important considering that they also enjoy the same right as others do. The South African Constitution aptly provides for right to education for everyone, visually impaired people inclusive and as such, they are entitled to enjoy the right without any limitation. Undoubtedly, if the infrastructure and teaching facilities at a university do not comply with the standard and the needs of the visually impaired people, barriers will be created, thus denying them the right to access to adequate education. The purposes of the guidelines are to set the acceptable international standards for amenities in any built environment, including universities that will conform to, and meet the needs of people with disability thereby fostering smooth movements and accessibility of any structure or area. While some universities, because of their vintage positions, have incorporated most of these standards into the structures s majority of the Historically Universities in South Africa have not. However, in view of the fact that a lot of black visually impaired people are now seeking and gaining admissions to the universities, there is need to upgrade the infrastructural amenities in the universities to the standard stipulated in the guidelines in order to cater for all students' need, especially the disabled. (Arnold, 2009). This will give the visually impaired people the opportunity to enjoy the right to education as envisaged in the Constitution.

The means of communication and information to the visually impaired is another major problem in the higher institutions. This is because most institutions do not have books available in braille and large prints.

Positive attitude will help propels the agenda for visually impaired people to a success story. It is now common knowledge that education is the single most important means to social class transformation for both individuals and communities globally (Baglieri and Shapiro, 2012). Therefore, visually impaired students should not be marginalized in the right of access to education as it is a life line for self-realization (Maret, 2008).

This paper will look into the need for government, together with higher learning institutions to make sure that learning conditions and infrastructure are better improved to accommodate the needs of visually impaired students (Adams and Brown, 2006). It will also look into the level of education and technical skills that are provided to the visually impaired students towards their contribution to equal responsibility and participation in the society.

\section{Methodology}

The method for this study was descriptive approach based on yearly assessments of the needs of virtually impaired students during admission processes, and during the course of pursuing their academic careers at the university (Brinckerhoff and Shaw, 1992). The Orientation and mobility Instructor (O\&M) visited, identified the problems areas and confirmed them. Thereafter, areas commonly used and not used by students with disabilities and the entire university community as a whole and its surrounding were assessed, evaluated and audited on a regular basis..

The reports of the findings were duly compiled and sent to the overall head and the director of the unit and thereafter submitted to the Committee for Persons with Disabilities for due deliberation and consideration for approval and action. The approval given will be submitted to the Technical Services Department for execution. It is the Technical Services Department responsibility, in collaboration with the Disable Students Units to ensure that the right and standard restructuring is done.

\section{Understanding Visual Impairments}

Visually impaired students are those that are blind (Wolffe et al. 2002). It could be partial or total blindness (Lieberman, 2002). Visual impairment occurs due to inability of the eye to receive light (WHO, 1980). It can be caused by an injury to the eye or a neural injury in the visual system which cannot be fixed or repaired by glasses or regular optic aids (Zihl, 2010). Visual impairment is considered as a huge constraint because it limits the individual's ability to recognize or see details in a sharp and accurate way from a defined distance (Paterson and Zangwill, 2000).

It is pertinent to draw a distinction between disability and impairment. Visual impairment is the physical fact of lack of vision (WHO, 2007). According to Oliver (1996), "disability is the social process in which the impairment cause negative implications to the individual due to barriers to access" ( Oliver, 1996). For an example, in a learning institution, one will note that blind students have impairments that limit vision, but this does not mean that they are disabled unless their learning materials are not accessible to them to function and move around. It is also to be noted that a visual impaired student will be able to walk around without assistance if he or she is using the cane with which he or she has been trained to move around with. This will give the visual impaired student access to every part of the university 
environment and the surrounding that has been designed to cater for all students' needs (Tzovaras et al. 2004). With the wherewithal, visual impaired students will be able to function as other students. (Chiat, 2001). The visual impaired only become disable when the wherewithal they will use to function are not accessible or provided.

\section{Motivation for the Study}

The key motivation for this study is to explain the importance of ensuring that structures and the environment are tailored to the needs of the students who are visually impaired. This is to enable them get the necessary support they need at the university to be able to cope and thrive like their mainstream counterparts (Bayram, 2014). It is also to accentuate on the enhancement of infrastructure to cater for all students regardless of their disabilities in order to deliver and improve teaching and active learning and produce excellent graduates. (Grace and Gravestock, 2008). The overall benefits of this is that, the drop out and dependency by students with visually impairment will decrease, and the number of enrolment will increase tremendously if the environment is accessible for all (Almog, 2011). More importantly, by restructuring to meet the needs of the visually impaired, the university will be fulfilling the constitutional mandates which prescribes that everyone has the right of access to education and that no one should be discriminated for whatever reason (Basser and Jones, 2011). To this end, the university community as a whole and its surrounding will also benefit from the restructuring that does not discriminate against anybody (Glazer, 1975). The facilities will also be useful to the community in case any venue is hired for an event, it will be seen that the facilities will cater for all that will come including the virtually impaired.

\section{The Significance of Restructuring}

It is important for the university to reflect the socio-cultural diversities of all the learners in whatever decisions are taken (Barajas and Owen, 2000). The need to create a conducive learning environment that will foster academic excellence becomes imperative when all the students are catered for without discrimination (Foster, 2005). It is also equally imperative for the university to be sensitive and able to discover areas that need to be improved on in order to provide equal opportune for all. This is the reason why one of the previously disadvantaged universities in South Africa has taken up the challenge to provide inclusive education for all, by ensuring that all the infrastructures and the environment students operate meet the needs of all including the visually impaired (Tjabane, 2010). The infrastructures are being redesigned and restructured in such a way that university community, including the visually impaired can be able to access services in the context of their daily routine.

\section{Thinking Out of the Box: The Conversation that Started the Need to Restructure}

Humans have different needs whether able or disabled. In an attempt to provide for these needs, there is the need to have the right mind and attitude (Bickenbach et al. 1999). With regard to the issues of disability, there is need to be sensitive to their plights before making any attempt to provide assistance that will meet their needs (Smith et al. 1995). It is important, while trying to provide assistance to the disabled, to have expertise and skilful people or organisation to provide the necessary and standard recommendation and execution of what needs to be done. , (Campbell and Oliver, 2013).

The key resource person to handle the issues and challenges of visually impaired students is the professionals' O\&M instructor (Phunong-ong, 2013). The expertise and skill of the O\&M are very important, especially in providing useful and meaningful professional advices to the university and the management (Sullivan, 2006). In a situation where the infrastructures of the university are not in conformity with the standard required to take care of the virtually impaired, the O\&M will have to think out of the box and advice the line managers and the management of the university on what to do to provide these facilities to cater for the needs of the visual impaired ( Picard and Pry, 2009). More importantly, the Disability unit at the University under which the O\&M functions usually aims to remove barriers preventing students with disabilities from thriving and participating equally like their able counterparts (Cooke, 2010). It is easier to engage with different stake holders through the disability unit via the overall head of the unit in conjunction with other staff members to present proposals that will ease the plights of the visually impaired (Adams and Brown, 2006). To forge ahead, it requires environmental assessment study and survey prior to the commencement of what needs to be done in order to have restructured, improved and standard infrastructures that will make the life of the visually impaired easier in a learning environment (Mittler, 2012). More importantly, the report confirming the findings that suggested infrastructure changes should be handed over directly to the Committee for Persons with Disabilities. It is after extensive deliberations and 
consultation which will culminate to the Committee's approval that the report can be submitted to Technical Services Department for study and action.

\section{The Role of O\&M Practitioner}

O\&M is the basic part in the comprehensive delivery of services to people with visual impairments. The O\&M can be in the schools, universities or rehabilitation settings (Heubner, 1995). Even though the core function of an Orientation and mobility instructor is to teach formal orientation and mobility skills to students with visual impairments, there is also the need for the instructor to assess the conduciveness of the environment for the visually impaired (Gilson and Dymond, 2011). The orientation and mobility will have little impact on students with visual impairments if the director of the Unit and committee for Persons with disabilities are not involved in the process (Mason and McCal, 2013). In addition the O\&M instructor should work cooperatively with the director of the disability unit and the university in developing realistic solutions to the plights of the visually impaired students in the university environment and its surrounding community ( Lieberman and Houston-Wilson, 2009). The reason for this is to cater for the needs and wellbeing of the visually impaired and other disabled persons at the university by ensuring that at the university, the available infrastructure should be able to, to a large extent, accommodated all students equally (Githinji, 2013).

The university should endeavour to create conditions which will help motivate and inspire students on constructive and creative learning (Powell, 2007). The Orientation and Mobility should also have the freedom to innovate and devise appropriate methods of communication and activities relevant to the concerns, needs and of students with visual impairments (Hersh and Johnson, 2010).

The infrastructure should be restructured in such a way that the university community can be accessed easily and safely in context of the impaired daily routine, recreational activities and so forth. When we speak of visual impairments, safety should be the priority (Prince, 2008).

\subsection{Disability awareness at the university community}

Disability awareness plays a vital role in any environment. It is one of the aspects that are most visible to the university community and management ( Albrecht and Devlieger, 1999). The use of disability awareness frequently carried out by the O\&M on campus to the members of the university community has been a major contributing factor in bridging the divides (Moon et al. 2012). The university now understands what inclusive education is, and has accepted the restructuring. Previous negative misconceptions and perceptions about disability, especially visually impaired have drastically reduced ( Baglieri and Shapiro, 2012).

\subsection{Restructuring to meet the visual impaired needs}

Infrastructures and facilities that are not accessible and easy to use by all students, especially the visually impaired should be restructured. Existing buildings that are not accessible should be restructured so that they accommodate students with visual impairment For example, audible device should be provided in areas where lifts are, and land marks for each floor should be unique in such a way that it will be easy to differentiate. (Klinger, 2014). All stairs in the buildings should be marked. Appropriate lightings available in corridors, lecture halls and library should be available to accommodate the partially sighted. Seating arrangements in lecture halls should be considered, for example, visually impaired should be given liberty to sit at the front.

\subsection{The benefits of restructuring}

Other universities especially those without Disability Units can benchmark and improve the accessibilities of their environment so that they accommodate, without discriminations, the needs of all students. Universities should I be able to properly provide support services and address the barriers experienced by students with visual impairments.

\section{Restructuring to Conform to Standard}

To restructure to meet the visually impaired needs, one of the professionals to be included in the planning and execution team should be the O\&M instructor (Bailey and Head, 1995). The skills and the knowledge of O\&M instructor are to 
assess visually impaired students and environment in such a way that will assist and determine the nature and the extent of services needed by them (Andersen et al. 2003). Also the O\&M assist to impart knowledge and skills to the visually impaired and other professionals in the university community (Scheiman et al. 2007).

The O\&M also has a duty to observe and point out defects in structures and amenities on campus such as flight of stairs on campus that are not marked and that pose a great danger to partially sighted students (Spungin et al. 2002). Lighting in lecture halls and corridors is also a challenge. The means and format of communication is also an issue. Most students complain about voices of lecturers not being audible enough, the writing on the board not bold enough and the fact that the lecturers never read aloud or repeat what they have said or written is a great challenge to students with visual impairment. It is important to reiterate that being visually impaired at the university environment is a challenge; hand outs from class are always on print. The notices on campus are not brailed or enlarged to accommodate visually impaired students. Thus, they always have to work harder than the able bodied counterparts to achieve good results. Furthermore, even though some lifts have audible devices sometimes, it takes a while to fix them when they are out of order. Digging holes, cutting branches and not having cars parked at the parking lots also cause disorientation and danger to visually impaired students. Signages on campus come with its challenges to students with visually impairment as they are unable to read them. Colour contrast in the lecture halls and buildings also cause some confusion to the visually impaired.

These are more infrastructural and facilities challenges facing the visually impaired students but the list is not exhausted or closed. From time to time, whenever another challenge arises, it will be pointed out for attention and correction.

\section{Describing Restructured Infrastructure}

Visually impaired people rely on audible, tactile cues and other sensory information from the surrounding environment for their orientation ( Cardin et al. 2010). Contrast between the walking surface and surrounding environment is critical for orientation and distinguishing the limit of the paths, recognising hazards and gathering information.

The paint that showed the pedestrian's crossings and speed humps on Campus were faded and it was difficult for the visually impaired students to access the crossings and identify humps (Medina et al. 2007). There was also no disability signage at all gates on Campus that warn motorist about students with disabilities. The stairs were not painted and most of them did not have the handrails that warn and prevent visually impaired students for any danger of the stairs.

\section{Challenges Encountered during Restructuring}

Undoubtedly, being a new phenomenon, there is the possibility for resistance of restructuring because changes will have to take place. A lot of meetings and presentations were held with the role players and stakeholders. By the time it was agreed upon that restructuring to meet the standard of virtually impaired should take place, the problem of execution to meet the standard also set in. It is at this stage that the O\&M stood her ground and advised on how and what should be done. This created an additional responsibility for the O\&M instructor because she has to attend to the needs of the students being her core duty, and at the same time played supervisory role over those who have the responsibility to effect reconstruction.

However, it is worthy to point out that the whole exercise is now a success story because due to the restructuring, visually impaired students now have more confidence when moving around on campus. They are now thriving and making giant strides in their studies within the university community because of ample access to all the facilities that will make teaching and learning easier.

\section{Conclusion}

The right to access education include but is not limited to providing education to all. It $t$ also ensures that the architectural infrastructure that will facilitate teaching and learning are designed to meet the needs of everyone. This is why it is within the ambit of the university to restructure to meet the needs and standard of students with visual impairments. By so doing, the university is putting into practice, educational transformation agenda of the South African government which mandates specifically that transformation should be implemented at all universities. Upgrading, redesigning the structures and other supporting educational facilities being used by the visual impaired students are typical examples of the demonstration of transformation and inclusive education that cater for all without any discrimination. 


\section{Recommendations}

Upgrading and restructuring should not be a one off transaction. They must be carried out as the need arise to achieve a complete inclusive educational environment. It is therefore incumbent on the O\&M to continue to identify areas for improvement, and make reports to the appropriate responsible department at the university through the overall head.

Creation of constant awareness to the entire university community on the importance and danger of any unpermitted changes to e redesigned and restructured of facilities to meet the needs of the visual impairments is very necessary. The cooperation of the whole university is needed for the success of the restructuring. Alteration by any means to the restructured facilities will disorientate the visual impairments students and could result to fatalities or unwarranted accidents. If there will be any alteration, the O\&M or the staff in the Disability Unit should be informed and thereafter, the experts will enlist the support of the university community before altering the signs.

\section{References}

Adams M, Brown S 2006. Towards Inclusive Learning in Higher Education: developing curricula for disabled students. Routledge, New York, USA.

Adams M, Brown S 2006. Towards Inclusive Learning in Higher Education: developing curricula for disabled students. Routledge, New York, USA.

Albrecht GL, Devlieger PJ 1999. The disability paradox: high quality of life against all odds. Social Science \& Medicine. 48(8): 977-988.

Almog N 2011. Academic and Social Adjustment of University Students with Visual Impairment. From http://in.bgu.ac.il/7D3A61828EBA-40AB-8869-B1948E8AA863/FinalDownload/Downloadld.DocLib1/Nitsansalmog.pdf. (Retrieved on 15 September, 2014).

Andersen E, C Bachofer, J Bell, A Corn, R Jose 2003. Providing access to the visual environment: A model of low vision services for children. From http://www.afb.org/JVIB/jvibabstractnew.asp?articleid=/JVIB/jvib970502. (Retrieved on 12 May, 2014).

Arnold PJ, Hammond, T, Clayton BM, 2009.South Africa's transition from apartheid: The role of professional closure in the experiences of black chartered accountants. Accounting, Organizations and Society. 34(6-7): 705-721.

Baglieri S, Shapiro A 2012. Disability studies and the inclusive classroom: Critical practices for creating least restrictive attitudes. Routledge, New York, USA.

Baglieri S, Shapiro A 2012. Disability studies and the inclusive classroom: Critical practices for creating least restrictive attitudes. Routledge, New York, USA.

Bailey BR, Head DN 1995. Providing O\&M services to children and youth with severe multiple disabilities. AFB Press, New York, USA.

Barajas M, Owen M 2000. Implementing virtual learning environments: Looking for holistic approach. From http://www.ifets.info/journals 13_3/barajas.pdf?origin=publication_detail. (Retrieved on 12 January, 2014).

Basser LA, Jones M, Rioux MH, Marks LÄB 2011. Critical perspectives on human rights and disability law. Mrtinus Nijhoff Publishers, The Netherlands.

Bayram G 2014. Exploring the academic and social challenges of visually impaired students in learning high school mathematics. Fromhttp://www.thesis.bilkent.edu.tr/0006669.pdf. (Retrieved on 5 September, 2014).

Bickenbach JE, Chatterij S, Badley EM, Üstün TB 1999. Models of disablement, universalism and the international classification of impairments, disabilities and handicaps. Social Science \& Medicine. 48(9): 1173-1187.

Brinckerhoff LC, Shaw SF 1992. Promoting access, accommodations, and independence for college students with learning disabilities. Journal of Learn Disability, 25(7): 417-429 .

Campbell J, Oliver M 2013. Disability politics: understanding our past, changing our future. Routledge, New York, USA.

Cardin S, Thalmann D, Vexo F 2010. A wearable system for mobility improvement of visually impaired people. The Visual Computer, 23(2): 109-118.

Chiat S 2001. Mapping theories of developmental language impairment: Premises, predictions and evidence. Language and Cognitive Processes, 16(2-3): 113-142.

Cooke B 2010. Voice of the Alliance for Equality of Blind Canadians. From blindcanadians.ca. (Retrieved on 24 August, 2014).

DPWSG 2001. Department of Public Works Standard Electrical, Mechanical and Architectural Guideline for the Design of Accessible Buildings (facilities for disabled persons).

Foster G 2005. The nature of educational inclusion for students diagnosed autistic spectrum disorder with challenging behaviours. From http://eprints.qut.edu.au/16167/. (Retrieved on 26 January, 2014).

Gilson C, Dymond S 2011. Constructions of disability at a university in Hong Kong: Perspectives of disabled students, staff members, and instructors. From http://dsq-sds.org/article/view/1589/1557. (Retrieved on 2 August, 2014).

Githinji JW 2013. Access To University Education For Persons With Disabilities: Towards Inclusion. From http://erepository.uonbi.ac. ke/handle/ 11295/62965. (Retrieved on 22 September, 2014).

Glazer N 1975. Affirmative discrimination: Ethnic inequality and public policy. Basic Press, New York.

Grace S, Gravestock P 2008. Inclusion and diversity: Meeting the needs of all students. Routledge, New York, USA.

Hersh M, Johnson MA 2010. Assistive technology for visually impaired and blind people. From http://books.google.co.za/books?hl= en\&lr=\&id=hibpnrahh-gc\&oi=fnd\&pg=pr5\&dq= =0bb1jttyxi\&sig=eoaclkhxpzmnd8u0uwbrtfvpfcctv=onepage\&q\&f=false. (Retrieved 
on 26 April, 2014).

Heubner KM 1995. Hand in hand: Essentials of communication and orientation and mobility for your students who are deaf-blind. AFB Press, New York, USA.

Klinger LE 2014. Scoping Review-Physical Accessibility \& Post-secondary Education. From http:/lir.lib.uwo.ca/cgi/ viewcontent.cgi?article=1006\&context=otpub\&sei-0easy\%20identify\%20floor\%22. (Retrieved on 12 September, 2014).

Lieberman LJ 2002. Perceived barriers to including students with visual impairments in general physical education. From http://digitalcommons.brockport.edu/pes_facpub/21/?utm_source=digitalcommons.brockport.edu\%2fpes_facpub\%2f21\&utm_med ium=pdf\&utm_campaign=pdfcoverpages. (Retrieved on $1 \overline{1}$ February, 2014).

Lieberman LJ, Houston-Wilson C 2009.Strategies for inclusion: A handbook for physical educators. From http://books.google.co.za/books?hl=en\&lr=\&id=0_mzrgery2yc\&oi=fnd\&pg=pr1\&dq=in =ecdr7ktwqx\&sig=pzwr979mhlxkfr2xqq|2egybyu0\#v=onepage\&q\&f=false. (Retrieved on 2 September, 2014).

Maret JD 2008. An ethnography of invisibility: Education \& special needs children in Japan. From http://scholarspace.manoa. hawaii.edu/handle/10125/20403. (Retrieved on 19 July, 2014).

Mason H, McCall S 2013. Visual impairment: Access to education for children and young people. David Fulton Publishers, Abingdon, UK.

Medina JC, Benekohal RF, Wang M 2007. Analysis of Pedestrians and Drivers Opinions on Crosswalk Safety at UIUC Campus. From http:/lict.illinois.edu/groups/tol/reports/TOLseries19.pdf. (Retrieved on 16 May, 2014).

Mitic D 2013. Health and work: how do residential disability support workers view their work? From http://vuir.vu.edu.au/22008/. (Retrieved on 16 June, 2014).

Mittler P 2012. Working towards inclusive education: Social contexts. David Fulton Publishers, Abingdon, UK.

Moon NW, Todd RL, Morton DL 2012. Accommodating students with disabilities in science, technology, engineering, and mathematics (STEM). From http://advance.cc.lehigh.edu/sites/advance.cc.lehigh.edu/files/accommodating.pdf. (Retrieved on 12 January, 2014).

NaickerSM 2005. Inclusive education in South Africa. Contextualising inclusive education, 2005. Routledge, Taylor \& Francis Group, London, UK.

Oliver M 1996. Defining impairment and disability: issues at stake. From http://disability-studies.leeds.ac.uk/files/library/Oliver-ex-divch3.pdf. (Retrieved on 18 June, 2014).

Paterson A, Zangwill OL 2000. Disorders of visual space perception associated with lesions of the right cerebral hemisphere. Routledge, New York, USA.

Phunong-ong P 2013. The roles and functions of support teachers for secondary school learners with visual impairment. From http://digital_collect.lib.buu.ac.th/journal/HRD_Journal/v2n1/p39-53.pdf. (Retrieved on 1 May, 2014).

Picard D, Pry R 2009. Does knowledge of spatial configuration in adults with visual impairments improve with tactile exposure to a smallscale model of their urban environment? From http://www.afb.org/jvib/jvibabstractNew.asp?articleid=jvib0304toc\&all. (Retrieved on 24 July, 2014).

Powell J 2007. Creative universities and their creative city-regions. From http://www.ingentaconnect.com/content/ip/ihe/2007/ 00000021/00000005/art00004. (Retrieved on 22 March, 2014).

Prince MJ 2008. Inclusive City Life: Persons with Disabilities and the Politics of Difference. http://dsq-sds.org/article/view/65/65. (Retrieved on 2 January, 2014).

Rieser R 2012. Implementing inclusive education: a Commonwealth guide to implementing Article 24 of the UN Convention on the Rights of Persons with Disabilities. Common Wealth Secretariat, Melbourne House, London, UK.

Scheiman M, Scheiman M, Whittaker S 2007. Low vision rehabilitation: A practical guide for occupational therapists. Slack Incorporated, New Jersey.

Smith JF, Runyan M K 1995. How Private Secondary Schools Can Meet Their Obligations to Accommodate Students with Specific Learning Disabilities. Western New England Law Review, 17:77-89.

Spungin SJ, McNear D, Torres I 2002. When you have a visually impaired student in your classroom: A guide for teachers. AFB Press, New York, USA.

Sullivan AD 2006. Transforming the University: Final Report of the Metrics and Measurements Task Force. From http://conservancy.umn.edu/handle/11299/5656. (Retrieved on 15 June, 2014).

Tjabane M 2010. Education policy and social justice in higher education: a South African case study. From http://www.repository.up.ac. za/handle/2263/24121. (Retrieved on 16 April, 2014).

Tzovaras D, Nikolakis G, Fergadis G 2004. Design and implementation of haptic virtual environments for the training of the visually impaired. From http://ieeexplore.ieee.org/xpl/freeabs_all.jsp?arnumber=1304867\&abstractAccess=no\&userType=inst. (Retrieved on 6 April, 2014).

Velázquez R 2010. Wearable and Autonomous Biomedical Devices and Systems for Smart Environment. Lecture Notes in Electrical Engineering, 75: 331-349.

WHO 1980. World Health Organization. . From http://apps.who.int/iris/handle/10665/41003. (Retrieved on 16 February, 2014).

WHO 2007. World Health Organization. International Classification of Functioning, Disability, and Health: Children \& Youth Version: ICFCY. Geneva, Switzerland.

Wolffe KE, SZ Sacks, AL Corn, JN Erin 2002. Teachers of Students with Visual Impairments: What Are They Teaching? From http://www.afb.org/JVIB/jvibabstractnew.asp?articleid=/JVIB/JVIB960502. (Retrieved on 14 May, 2014).

Zihl J 2010. Rehabilitation of visual disorders after brain injury. Psychology Press, New York, USA. 